\title{
Relevant Aspects of the Integration of Post-Soviet Countries in the Project of the Eurasian Economic Space
}

\author{
Irina Valerievna Leskova ${ }^{1}$, Dmitry Nikolaevich Ermakov ${ }^{1}$, Galina Ivanovna Andruschenko ${ }^{1}$, Sergey Valerievich \\ Raspopov $^{1} \&$ Svetlana Anatolievna Khmelevskaya ${ }^{2}$ \\ ${ }^{1}$ Russian State Social University, Moscow, Russian Federation \\ ${ }^{2}$ Lomonosov Moscow State University, Moscow, Russian Federation \\ Correspondence: Irina Valerievna Leskova, V. Pika, 4, 1, Moscow, 129226, Russian Federation
}

Received: February 28, 2015 Accepted: March 20, 2015 Online Published: April 26, 2015

doi:10.5539/res.v7n6p231 URL: http://dx.doi.org/10.5539/res.v7n6p231

\begin{abstract}
Presents an analytical article reveals the socio-political conditions of integration of post-Soviet States in a globalized world, and competition international alliances. The main stages of socio-economic integration of the CIS countries in the post-Soviet space from the Commonwealth of independent States, Eurasian economic community, Customs Union. A special place is occupied by the discussion of issues related to the future established by Russia, Belarus and Kazakhstan in Astana on May 29, 2014 Eurasian economic Union (EEU). Discusses some of the factors integration processes associated with the minds of the broad masses of the population of the three countries and with the specifics of the quality and mentality of their "elite".
\end{abstract}

Keywords: integration in the post-Soviet space, the common economic space, the Eurasian economic community, the Eurasian economic union, Customs Union

\section{Introduction}

The globalization of the world financial system leads to the emergence of regional economic integration, which is the objective law of economic cooperation in inter-state and supra-state bodies and organizations.

In the process of integration observed convergence of national economies, the transition to the single currency, the creation of a common system of standards, unification of customs and investment legislation. The highest form of economic integration is the creation of a unified legislative and Executive power, the blurring of boundaries in the legal status of citizens of member States of the Union. Economic conditions do not always lead to partial political cooperation, the situation when the country voluntarily limits their sovereignty in favor of supranational bodies.

The Russian Federation is an active participant in the integration processes in the post-Soviet space. In December 1991, the former Soviet republics (except the Baltic States and Georgia signed an agreement on creation of the Commonwealth of Independent States (The agreement establishing the Commonwealth of Independent States, 1991). In the Commonwealth of Independent States, including 11 countries participating formed by intergovernmental bodies. In parallel with participation in the CIS, the Russian Federation and the Republic of Belarus on December 8, 1999 they signed the Treaty establishing the Union state.

With a share of regret we have to admit that today, the Commonwealth has turned into a "club of countries by area of interest. This is the main reason for Russia's aspirations to focus on the establishment of a more integrated unions (collective security Treaty organization, a Russian-Belarusian Union state (the Treaty establishing the Union state, 2000), Eurasian economic community (the Treaty establishing the Eurasian economic community, 2002), Customs Union (the Treaty establishing a single customs territory and formation of the customs Union, 2011), the Eurasian economic Union. According to the own correspondent of "Novaya Gazeta" in the Republic of Belarus Iryna Khalip CIS "from the outset it was no Commonwealth and the organization of consumers of Russian gas" (Khalip, 2014).

In the Commonwealth of Independent States, including formally 11 participating countries (Ukraine has not ratified the CIS Charter, Turkmenistan has associate membership, Georgia withdrew from the CIS in 2008, Moldova gradually drifting towards the EU) formed by intergovernmental bodies. These include: the Council of heads of States, Council of heads of governments, the Council of Ministers of foreign Affairs, the Economic 
Council, the Economic Court of the CIS, the CIS Executive Committee, the Council of permanent Plenipotentiary representatives of the States-participants of CIS in the statutory and other bodies of the Commonwealth, the Commission on economic matters at the CIS Economic Council. However, the decisions and agreements are of recommendatory nature. For grouping States into mutually beneficial alliances prerequisites: socio-economic (Kryukova et al., 2015), political, social, environmental, cultural, need to ensure national security.

Socio-economic suppose the common models of the economy, standardization of accounting systems and financial reporting, integration processes between enterprises for the purposes of the division of labor between the countries of the Union. CIS countries show a fairly modest economic performance: in 2012, their share of GDP in the world economy was only 4, 2 percent (World Economic Outlook Databas, 2013). Important unifying factor is the unification of law, the unity of the transport system, common borders, and the mentality of the population.

Despite the rather pessimistic assessment of the future of the CIS, the value of this integration Association the faucet is great. Accumulated by the Commonwealth of experience seamlessly blended and was reasonably used to transition to the Eurasian economic Union. An important milestone in the history of the Eurasian economic community was the creation of the Customs Union, the borders of which are the common customs tariff. The obvious advantage of EurAsEC was the increase of commodity turnover between the countries during 2007-2009 were formed of a single customs space, enabling Russia, Belarus and Kazakhstan from January 2012 to reach a new stage of integration-the Single economic space. The strategic goal of the CES is the free movement of goods, services, labor across borders of member States.

The next important step towards the integration of the three States was signed by Russia, Belarus and Kazakhstan in Astana on May 29, 2014 the Treaty on the Eurasian economic Union (EEU) (The Treaty on the Eurasian economic Union, 2014).

From September 2014 the decision to create in the framework of the Euro-Asian economic Union of the Common economic space of Russia, Belarus and Kazakhstan (CES) has gained more than realistic. The Treaty on the Eurasian economic Union shall enter into force on 1 January 2015, and its individual provisions in 2015-2018. Postponement necessary for proper operation of the EAEC. At the present time to the Eurasian economic Union joined the Republic of Armenia (Resolution of the Government of the Russian Federation from August 11, 2014).

The main goal of this large-scale economic and geopolitical project is the creation of conditions for sustainable and effective development of the economies of member States and improve people's lives. Of course, nobody cancelled and associated solutions to a number of important geopolitical objectives.

The probability of overall success of such large-scale undertakings associated not only with economic and political interests of the member countries, not only based on personal ambitions and wishes of their leaders, but also has some historical background.

For centuries, Russia, and the efforts of rulers, and as civilization, with immense effort uniting the vast Eurasian space. And this Association existed in the political form of the Russian state, and later the Soviet Union. However, at the end of the last century there was the collapse of the USSR, which was now in the opinion of the Russian leadership, geopolitical catastrophe. We have received several serious conflicts (Nagorno-Karabakh, Georgia, Transnistria, the Chechen Republic, Tajikistan), economic catastrophe, General degradation and barbarization society manifested primarily in the mass impoverishment of the population, a total of anomie, the state of the most significant areas of regulation of the society and the rapid development of natural processes "wild" prestructural society in which material and social position of the individual groups (or individuals) dramatically improved due to General sharp deterioration of the situation in the society as a whole. All this was manifested both in Russia and in most of the independent countries that emerged on the territory of the former USSR.

\section{Method}

As a methodological basis of research in the study of the evolution of integration processes in the post-Soviet space was used the dialectical method, the principle of the unity of the historical and logical. The authors presented a comprehensive historical retrospective and contents of the key stages of the formation of international alliances on the territory of the former Soviet Union. Studied in detail diametrically opposing views about the nature and prospects of integration associations in the post-Soviet space. When analyzing the activities of the Eurasian economic Union, applied structural-functional method. The article made a successful attempt to 
consider integration in the post-Soviet space in close context with the processes of global geopolitics. Concluded that unfavorable for Russia's economic situation and the regime of international sanctions imposed in connection with the situation around the Crimea, forcing the Russian government to create all sorts of unions and associations in order to preserve its lost influence in former Soviet republics. The authors analyze the basic legal documents governing the operation of the EAEC. The study of foreign experience of integration in the European Union demanded the use of the benchmarking method and comparative method. The application of the method comparisons revealed distinctive features of the European integration of free Nations, created a highly innovative economy and the Eurasian Union countries "peripheral capitalism".

Information-empirical base of the research was the official data of the Ministry of economic development of the Russian Federation, Federal service of state statistics of the Russian Federation, Ministry of economy of the Republic of Belarus, National statistical Committee of the Republic of Belarus, Ministry of national economy of the Republic of Kazakhstan (Gavrilov, 2014), the Russian and foreign periodicals, Internet resources.

\section{Results}

The analysis of the regulatory framework of the Eurasian economic Union has allowed to revealing the main goals and directions of active new international institution. In Article 4 of the Treaty establishing the EAEC sets the goals of the Eurasian economic Union. These include, first and foremost, the creation of conditions for stable development of the economies of member States in the interests of improving the living standards of their populations, the desire to create a single market of goods, services, capital and labour within the Union. No less important a comprehensive modernization, cooperation and competitiveness of national economies into the global economy.

\subsection{Consider the Structure of the General Authorities of the EEU}

Interstate bodies of the Eurasian economic Union, largely created by analogy with the supranational institutions of the European Union. Authorities EEU: the Supreme Eurasian economic Council (the Supreme Council); intergovernmental Council of the Eurasian (intergovernmental Council); the Eurasian economic Commission (Commission of the EEC); the Court of the Eurasian economic Union (court of the Union). In the composition of the High Council is composed of heads of States parties.

The Supreme Council consists of the heads of member States of the Union. In article 12 of the Treaty on the Eurasian economic Union defined its powers.

First, the Supreme Council determines the strategy, direction and prospects of formation and development of the Union and makes decisions aimed at implementing the objectives of the Union. Secondly, approves the composition of the Board of the Commission, distributes duties between the members of the Board of a Fee and terminate their appointments. The Supreme Council shall appoint the Chairman of the Board of a Fee and take a decision on early termination of his powers, also assigns the representation of the member States of the judges of the Court of the Union. The Supreme Council approves the Regulations of the Eurasian economic Commission and the budget of the Union Position on the budget of the Eurasian economic Union and the report on execution of the budget of the Union, determines the size (scale) contributions of member States to the budget of the Union.

Intergovernmental Council is the organ of the Union, consisting of the heads of governments. Article 16 of the Treaty establishing the Eurasian economic Union is determined by its competence. Intergovernmental Council provides the implementation and monitoring of the execution of this Agreement, international treaties within the framework of the Union and the decisions of the Supreme Council considers the proposal of the Board of commissioners issues that when making decisions in the Council of the Commission is not a consensus.

The Commission is a permanent governing body of the Union. The Commission consists of the Council and the Board. Powers of the Commission are set out in Annex 1 to the Treaty establishing the EAEC.

The Commission carries out its activities in the following areas: customs tariff and non-tariff regulation, technical regulation, sanitary, veterinary-sanitary and phytosanitary measures. Also the jurisdiction of the Commission include: the establishment of trade regimes in relation to third parties, macroeconomic and competition policy, policy, industrial and agricultural subsidies, energy policy. The competence of the courts of the Union are defined in Appendix 2 of the Statute of the Court of the Eurasian economic Union" to the Treaty establishing the Eurasian economic Union. Court of the Union shall resolve disputes arising from the implementation of the Agreement, international treaties of the Union and (or) decisions of the organs of the Union:

1) At the request of a member state: 
- Compliance with international agreement within the Union or its individual provisions of the Contract; about compliance by another member state (other member States) of the Agreement, international treaties of the Union and (or) decisions of the organs of the Union, as well as certain provisions of these international agreements and (or) decisions;

- On the conformity of decisions of the Commission or its individual provisions of the Agreement, international treaties of the Union and (or) decisions of the organs of the Union;

- Challenging actions (inaction) of the Commission.

2) Upon request of the entity:

- On the conformity of decisions of the Commission or its individual provisions, directly affecting the rights and legitimate interests of the economic entity in the sphere of entrepreneurial and other economic activities;

- Challenging actions (inaction) of the Commission, directly affecting the rights and legitimate interests of the economic entity in the sphere of entrepreneurial and other economic activities, if such action (inaction) caused the violation provided by the Contract and (or) international treaties of the Union the rights and legitimate interests of the economic entity.

The court of the Eurasian economic Union leaves without claims for damages or other property claims. The analysis of competences intergovernmental bodies EEU, which are discretionary in nature, largely reflects the General trend of legal and institutional vagueness created education.

\subsection{Consider the Economic Component of the EEU}

The article identified the prospects of success of a new integration of education, which, to a large extent, based on the mentality of the peoples of the former USSR. Currently, as in the Russian society, and in several other countries of the former Soviet republics are becoming increasingly popular as reflected in public opinion positive "memories" about the common past in a single country; in limiting their expressions, they reproduce the past as a "lost Paradise". This is an indicator that among ordinary people, it is very important commitment to the new Association, as some reasonable alternative to a scattered existence of countries and their peoples. After all, euphoric hopes 90s that individually would be better by now outlived its usefulness. Indeed, the years of independence has not brought independent countries neither prosperity nor peace. During this time, the post-Soviet space have experienced not only a number of wars, and genocide, the living standards of the broad masses of the population has decreased in comparison with the late Soviet; significantly increased crime rates; demographic processes in several countries came to the brink of disaster. And it is increasingly seen as the understanding that in the current geopolitical and macroeconomic conditions our countries in a fragmented state will not be able to achieve any worthy life for the masses of the population, nor sustainable security. Among the "elites," as Russian and other designated countries, is relevant to the issue of integration is more complex and the pursuit of it is expressed not so clear, however, the representatives of these groups comes the expediency of giving more serious attention to the joint, within the EEA, international projects.

Eurasian space again faces the problem of unification. And it is from Russia - the country with the most powerful economy in the post-Soviet space partners are waiting for the initiative in this matter.

In our days the Eurasian integration is of particular importance for most countries of the region. After all, with States competing in the global economy today is published on the competition between the integration blocks. This applies to the European and Eurasian unions.

Combining economic, political, human and management resources within the EEA are able to bring to the countries participating in the many benefits that can manifest itself in economic, social and political spheres.

The most important aspects of attraction in the field of Economics.

The acceleration of economic development in the region, creating new jobs and increasing incomes, and real support for entrepreneurs the freedom of choice of the country or administrative territory of registration of your business that may be provided by a combination of the following overlapping circumstances.

That: Ensuring the business case conditions for the production of competitive products and modernization of enterprises; integrated market, in case of its full establishment, will be more attractive for mutual investment and investment in third countries; to improve access to infrastructure in energy, transport and communications; improving the productivity of interaction between business and government.

Significant relief freedom of movement within Russia, Belarus, Armenia and Kazakhstan capital, labor and services, driven by the creation in 2011 of the Customs Union of these countries, essentially, opened a real 
perspective to the institutional formation of the functioning of the common economic space.

Representatives of the liberal democratic part of the Russian civil society, evaluating the events of September this year, has expressed serious concerns about the availability of any of the economic background of the EEU. Again, we refer to the opinion of the own correspondent of "Novaya Gazeta" in Belarus Iryna Khalip: "If there is, in Belovezhskaya Pushcha, the CIS was conceived as a form of equal partnership, the Customs Union from the very beginning was the project of the Russian, not the interstate. After CU in Belarus in 2011 there was a default, and wages decreased by three times. Then we put huge tariffs on imported cars, which has never happened before. That is, Belarus did not win anything, but Russia upheld customs duties on most goods contrary signed the Customs code. So the economic component even be considered funny is one big hoax. The customs Union is a personal response, Putin West instead of quietly dying CIS.

And when you consider that the Customs Union intend to join unrecognized Abkhazia, South Ossetia, Transnistria war-torn Syria, it can be argued that this new Covenant is not only the Russian response to the enlargement of the EU, but also potentially dangerous for the world Association of rogue regimes. There is no economic component in all these countries and unrecognized territories are too small trade with each other (but with considerable Russia) and do not require additional unification schemes. But Russia is ready to take not quality, but quantity, and to increase their influence in the world according to the principle "let all fear" (Khalip, 2014).

On the contrary, the representatives of the national-Patriotic part of the civil society and leading scientists emphasize the likelihood of overall success of such large-scale undertakings, which is associated not only with economic and political interests of the participating countries, but also has some historical background. In particular, the head of the Department of international capital markets at the Institute of world economy and international relations RAS Yakov Mirkin says: "The Creation of the EEU gives a larger market. That will provide the opportunity to better meet the demand of consumers, to increase competition. This gives freedom of movement of personnel, capital and goods. And means a better quality of life-gain because of the larger number of players to meet demand. Will be able to overcome the tendency of open economies. Recently fell the trade turnover between the countries of the Customs Union. And we must re-connect the economy and financial sector of our countries."

\subsection{Key Aspects of Attractiveness in Social Terms}

Optimization of relations in the labor market (Ilina et al., 2014) as a consequence of the simplification of movement of labor and the increased purchasing power of the population, could lead to the reduction of social tension in the participating countries and to help to overcome distortions in the housing markets, which was formed in the Soviet times and unresolved to this day.

The most orderly statement of understanding of what are the benefits of cooperation between the countries within the Customs Union and the Common economic space, and in what forms it contributes to national economies, to strengthen economic ties and the output member countries to a new level of integration and interaction presents Kostyuchenko (2014).

Here - and the free movement of goods on the basis of unification of customs tariffs; the formation of a common customs tariff and non-tariff regulation measures; the use of instruments to regulate trade in goods with third countries, as the economic benefits resulting from cooperation between Russia, Belarus and Kazakhstan within the Customs Union, the single economic space with the formation of a viable supranational regulatory authority trilateral economic relations - the Commission of the Customs Union.

This - and the ability to influence in order to strengthen positions in the world economy; and the potential of Belarus as a transit corridor to Europe for Russia. For Belarus, is the access to the Russian markets and cheap energy, the more that Russia in the Belarusian economy is the largest exporter of goods. What was the economic result of cooperation between Russia and Belarus in the framework of the Treaty establishing the Union state.

With regard to bilateral cooperation "tandem" Russia—Kazakhstan (Kryukova \& Makeeva , 2013; Kryukova et al., 2013), as a result of joint participation in the composition of the major economic, military-political international organizations that, as the economic effect, for Russia has provided a large number of commodity and transport flows, as well as access of Russian business to the important natural resources of Kazakhstan; Kazakhstan - the possibility of the development of the internal market with a view to enter into the world economy, and protection from economic pressure China.

Speaking about the partnership, Belarus and Kazakhstan, the result of their interaction (in this context) was the Treaty of friendship and cooperation and the Agreement on long-term economic cooperation for 2009-2016, that 
brought the economic effect of strengthening trade and economic cooperation due to the increase in export-import operations (Leskov, 2014).

As for the political attractiveness, although she is devoted to this work, we note that the political aspects of cooperation are very important and no less important than economic or social, but they are able to exert influence both magnetic and centrifugal in nature. In response to the latter, note that, along with the desire for integration, it is noted, also, and some resistance EEA political integration in the post-Soviet space, which is expressed primarily in the specific interest of their leadership to other options of inter-state alliances. Thus, Kazakhstan's leadership clearly sees, in addition to the CES, the ability of the country to participate in "Turkic Union", involving the Association of such countries as Kyrgyzstan, Kazakhstan (Mansurov, 2014), Uzbekistan, Turkmenistan, Azerbaijan, Turkey and the Turkish Republic of Cyprus; also a notable contender for the creation of economic alliances for Russia and Kazakhstan so far is China.

\section{Discussion}

President of the Russian Union of Industrialists and entrepreneurs, A. N. Shokhin appreciated the importance of the Eurasian economic Union in the integration process: "The signing of the Treaty on the Eurasian economic Union has become a new step in the deepening of integration in the post-Soviet space. There were several innovations in terms of regulation at the supranational level of investment processes, labor migration and other critical business issues. For example, social insurance for workers of member States (except pension) will be carried out under the same conditions and in the same manner as nationals of the state of employment" (Shokhin, 2014).

According to the expert of the center of research of political thought and ideology (Center Sulakshin) Lyudmila Kravchenko: "Initially, the idea was not economic, but in some kind of political integration, the mention of this was contained in the first edition of the Treaty of Union. Subsequently, however, the idea of contract was edited in such a way that in principle it remained the same provisions already laid down in the Customs Union and Common economic space. What's new appears now? This in-depth integration on areas that were already marked it and transport, and energy, and investment, and agriculture" (Trefilov \& Shary, 2014).

Bleak prospects of the Eurasian economic Union predicts expert Andrey Cherepanov invited to transfer the leading Andrei Sokolov international radio station "Freedom". In his view, created by Russia unions represent "a house of cards, of which I spoke, it includes not only the situation within the country is and the position of all these not so long ago-created organizations, as they were based solely on the money that was earned due to high oil prices and nursed including these organizations. Russia lost, but politically she won something. Once was all it pour as soon as money in Russia has become much less, these unions were successfully completed its existence. I believe that such customs can be a constant between Russia and Belarus, then between Russia and Kazakhstan, it is unlikely that someone will join this Union in the future. Therefore, there is serious speculation that it was seriously and permanently" (Medvedev assured Russia in collapse, 2014).

It is assumed that one of the major achievements of the next period should be the creation of a common financial market to obtain financial companies in countries participating in the EEA access to national markets to each other.

Among the positive effects are expected to increase the availability of financial resources for Kazakh, Russian and Belarusian financial institutions along with increased competition in cross-country (EAAP) level. Forecasted and mutual increase in the volume of services of banks, insurance companies and participants of the securities market of each country, provided on the markets of member States.

Unfortunately, this is not without some problems.

Waiting for each state included in the CES, the adverse consequences for a number of national industries slows down the adoption of common solutions.

For Kazakhstan, with its characteristic distortion of export in the direction of mineral resources and the consequent dependence on world market demand for them, these industries are considered to be the most "non-extractive" industries, including banking or agro-industrial complex with its technological lag (Ermakov, 2014). For Belarus is clearly problematic sector is the agricultural sector. But here is the issue of subsidies. In fact, after the CU Minsk cannot arbitrarily determine the budgetary funds in the form of subsidies on agricultural support: according to the rules of a common competition policy EEA, partners may require reduction. In addition, the CES removes obstacles for the Russian and Kazakh capital in the course of privatization in Belarus.

For Russia, too, not all factors integration favorable. With the launch of the common economic space, Russia had to abandon subsidizing their national automotive industry and manufacturers of agricultural machinery. 
You can select a number of problems of a General nature.

First, is the issue of reliability and completeness of customs notification, exchange of information between customs services of the customs Union.

Secondly, is the so-called "aggregation problem", which is expressed in the absence of statistical interaction (about half of the enterprises in the three countries do not report statistical bodies information about the results of their activities).

And, thirdly, with the development of the CES also actively began to form the conditions for the "flow" of capital and liquid assets from countries with more stringent regulatory requirements in countries with relatively soft regulation.

The initiators of the project of creation of the CES characterize it as a promising and is designed for a sizeable increase in profits derived from all participants in the foreseeable future.

However, in reality, the creation of the CES takes place in the context of a complex system of geopolitical relationships of many States, which attempts to interfere West stringray active, and not the last role.

For our Anglo-Saxon partners Central Asia has always been, and remains stable territory attractiveness. State of the Central Asian region is rich in unique natural resources. In addition, for the Western powers is very useful from a geopolitical point of view to be in their sphere of influence of such a strategically important region.

However, to expand its influence, they face a number of obstacles, among which the influence of Russia and China in the region (Ermakov, 2015).

\section{Conclusion}

The CES project, which is implemented based on the experience of the European Union. Will take the liberty to say that one of the main reasons that it is built taking into account the experience and not solely by mask creation of the EU in the following: there are striking differences in mentality, the differences between transition economies and the specific traditions of political-administrative culture in the post-Soviet space from what is observed and developed in the West, in countries with developed traditions of a market economy and electoral democracy. The European Union unites the free Nations of the civilized market economy and democratic political systems. Unfortunately, these characteristics do not fit into any of the post-Soviet countries involved in the integration processes in the post-Soviet space.

Another tangle of problems on the way of Eurasian integration in the post-Soviet space is associated with the specifics of the elites in the post-Soviet space. On the one hand, to their representatives characterized by the presence of quite a large number of features in common mentality, inherited from the Soviet party-hsnomenclatures. It certainly should help to facilitate finding a "common language" in the process of building a common economic space of the Eurasian space. But, on the other hand, in some cases we can observe in the environment of their representatives complete lack of patriotism for the sake of greed, absolute, not even immorality, but I ought to say, vnemoralnost; and "genetic" desire to give priority to the clan (in Asian countries) and corporate (in Russia and, apparently, Belarus) the interests of the state.

Thus, it is possible to talk about significant prospects of integration of Belarus, Kazakhstan and Russia within the EEA. One can only regret about the failure of Ukraine's integration into the Customs Union. Our Ukrainian partners were not able to achieve the optimal combination of simultaneous participation in the Customs Union and the EAEC and the prospects for progress towards a European Union. If we consider the existing and possible problems and obstacles to integration processes, they too are complex and are rooted not only in the specifics of economic development and mentality of the "elite" of the three countries, but also in the characteristics of the overall geopolitical situation in the world.

\section{Reference}

Ermakov, A. N. (2014). Political processes of socio-economic integration of the countries-participants of the Commonwealth of Independent States: Situation and perspectives. Bulletin MGOU, 4. Retrieved from http://evestnik-mgou.ru

Ermakov, A. N. (2015). The content of the political processes of economic integration in the post-Soviet space. Law and the state: Theory and practice, 2.

Gavrilov, A. (2014). Bajkonur space launching site: Historical and legal aspect of Russian-Kazakh relations. Life Sci J, 11(5), 469-472.

Ilina, I. Y., Belotelova, N. P., Danilina, E. I., Novikova, D. M., \& Pochinok N. B. (2014). "Professorate 
Unemployment" in the Modern Russia. Asian Social Science, 10(24).

Irina, K. (2014). Goodbye, CIS. Retrieved December 12, 2014, from http://www.novayagazeta.ru/politics/65808.html

Kaurova, O., Maloletko, A., \& Yumanova, O. (2013). Cross-country Comparison of Statistical Indicators. Life Science Journal, 10(4), 1915-1917.

Kostyuchenko, E. C. (2012). Economic integration of the countries of the Customs Union of Russia, Belarus and Kazakhstan in the world community. Volgograd, 14(16), 29-34.

Kryukova, E. M., \& Makeeva, D. R. (2013). Analysis of world and Russian best practices of strategic development of mono-towns. World Applied Sciences Journal, 27, 167-171.

Kryukova, E. M., Razumovskiy, S. L., \& Vetrova, E. A. (2013). Mono-town in the system of economic notions of the Russian Federation. World Applied Sciences Journal, 27, 162-166.

Kryukova, E. M., Vetrova, E. A., Maloletko, A. N., Kaurova, O. V., \& Dusenko, S. V. (2015). Social-Economic Problems of Russian Mono-Towns. Asian Social Science, 11(1), 258-267.

Leskov, I. C. (2014). Eurasian economic space: Achievements and problems of the project. The Right and the state: Theory and practice, 12.

Mansurov, S. (2014). Eurasian project Nursultan Nazarbayev, embodied in life. In For the 20th anniversary of the Eurasian project 1994-2014. M.

Medvedev assured Russia in collapse. (2014). Retrieved December 12, 2014, from http://www.svoboda.org/content/transcript/26735071.html

Shokhin, A. N. (2014). Abstracts of presentations at the Meeting of the Advisory Council for cooperation of ECE with the Belarusian-Kazakh-Russian business dialogue. Retrieved December 10, 2014, from $\mathrm{http} / / \mathrm{RSPP} . \mathrm{RF} / \mathrm{viewpoint/view/503}$

The agreement establishing the Commonwealth of Independent States. (2014). Retrieved December 10, 2014, from $\mathrm{http} / / /$ base.consultant.ru/cons/cgi/online.cgi?req=doc;base=LAW; $=30726$

The agreement on establishment of the Eurasian economic community. (2002). Collected legislation of the Russian Federation, 7. Retrieved December 10, 2014, from http://www.szrf.ru/doc.phtml?nb=edition00\&issid=2002007000\&docid=4

The Treaty establishing a single customs territory and formation of the customs Union. (2011). Collected legislation of the Russian Federation, 12. Retrieved December 10, 2014, from $\mathrm{http}: / /$ www.szrf.ru/doc.phtml?nb=edition00\&issid=2011012000\&docid=126

The Treaty establishing the Union state. (2000). Collected legislation of the Russian Federation, 7. Retrieved December 10, 2014, from http://www.szrf.ru/doc.phtml?nb=edition00\&issid=2000007000\&docid=1

The Treaty on the Eurasian economic Union. (2014). Retrieved December 10, 2014, from http://www.consultant.EN/document/cons_doc_LAW_163855/

Trefilov, I., \& Andrei, S. (2014). The Union of three. Retrieved December 10, 2014, from http://www.svoboda.org/content/article/25402793.html

World Economic Outlook Databas. (2013, October). International Monetary Fund. Retrieved December 10, 2014, from http://www.imf.org/external/pubs/ft/weo/2013/02/weodata/index.aspx

\section{Copyrights}

Copyright for this article is retained by the author(s), with first publication rights granted to the journal.

This is an open-access article distributed under the terms and conditions of the Creative Commons Attribution license (http://creativecommons.org/licenses/by/3.0/). 